\title{
Open innovation and user's involvement in new product development: a case study in the automotive sector
}

\author{
Sérgio Ricardo Mazinia ${ }^{a}, J o s e ́$ Alcides Gobbo Junior ${ }^{a}$, Daniel Jugenda, Sérgio Luis da Silva ${ }^{b}$ \\ ¿São Paulo State University \\ bFederal University of São Carlos \\ e-mails: sergio.mazini@oriongestao.com.br; gobbo@feb.unesp.br; danie@@eb.unesp.br; sergiol.ufscar@gmail.com
}

\begin{abstract}
Innovation is an essential factor for obtaining competitive advantages. The search for external knowledge sources for product creation, which can contribute to the innovation process, has become a constant among companies, and users play an important role in this search. In this study, we aimed to analyze user's involvement in the product development process based on open innovation concepts. We used the unique case study research method. This study was carried out in an automotive company that has developed a project of a concept car involving user's through the Web 2.0. With such scope, the research demonstrates that users can contribute not only with generation of ideas but also with the innovation process itself.
\end{abstract}

Keywords: open innovation; user driven innovation, new product development.

\section{Introduction}

Nowadays, external sources of knowledge and information are factors considered relevant in activities of new products innovation and development. The open innovation has become an effective concept to provide search of external sources. The concept introduced by Chesbrough (2003) proposes an approach for the innovation through collaboration of various actors in the value chain and for the search of new knowledge and technologies. Ryzhova (2009) and Vrande et al. (2009) consider this as a fairly new concept, which has attracted large amount of companies and researchers attention.

Overall, the open innovation paradigm suggests that companies look for partnerships and involvement with other actors (normally external ones) that may contribute with the innovation process, among which are the costumers themselves. Ability to identify and engage customers throughout the innovation process can be considered a key factor to the performance of the innovative activities of a company (LETTL et al. 2006).

The open innovation approach has been flaunted by the area of innovation management and technology contemporary literature, because, with the current speed and diversity of technological change, it becomes difficult, if not impossible, for companies to ensure their competitiveness through unique and exclusive internal development of new technologies. Even counting on excellent and qualified internal professionals - very often linked to $P \& D$, many companies from the technology area realize that they cannot remain innovative and competitive in the market, without being able to share information, knowledge and solutions to companies, institutions and professionals.

Information and communication technologies are contributing with less transaction costs, easy access for the costumers participation in all phases of product development process, what permits performance improvement not only on costs and development time, but also projecting what costumers really want (MATTOS; LAURINDO, 2008). By modifying the processes of a company, information and communication technology impact the customer relationship, which can affect the process of product development (DAHAN; HAUSER, 2002). Internet, as also, created new opportunities for integration with customers. The web-based tools can simplify this integration and also the absorption of knowledge, favoring interaction between company and customers (PRANDELLI; VERONA; RACCAGNI, 2006).

Involved in this context, the purpose of this article consists in presenting and analyzing, through an unique case study, the involvement of users through the Web 2.0 in the innovation process and new products development. The empirical research was held at the auto company and the agency that has made the digital interaction design with users. It is worth noting that according to the manager of the Style Center of the Auto company in Brazil, the project is a paradigm break in the worldwide automotive industry 
because no automaker "has opened" so far the process of developing a new car (WENTZ, 2010).

A brief bibliographic review about the theme is done initially. It is approached the research method used. Next, results of the case study are presented and discussed. At last, the final considerations are presented.

\section{Literature review}

\subsection{Open innovation}

Classic contemporary publications in the management area are emphatic about pointing to innovation as one of the main directions for businesses to prosper, grow and sustain competitive advantage (CHRISTENSEN, 1997; DRUCKER, 1988). The recent open innovation model proposed to the innovation management is based on the need of the companies to open their traditionally closed innovation process and combine internal and external development for the creation of value in business.

The Open Innovation term was firstly proposed by Chesbrough (2003) and it refers to organizations abilities to systematize the search of ideas, information and knowledge present outside of the company. For Chesbrough (2003), the innovation process of many companies is changing from the "closed innovation" to the "open innovation" model. The open innovation emphasizes the importance of the use of external knowledge sources for the better performance, especially in terms of richness of ideas, of the innovation process.

In the previous paradigm of closed innovation, companies had joined the philosophy that an innovation to be successful requires control. In other words, companies must create their own ideas and then develop them for the market, as Figure 1 illustrates.

In the late twentieth century, however, a combination of factors deconstructed the fundamentals of closed innovation in the United States. Perhaps, among these factors had been the increase in the number and mobility of knowledge workers, which made an incredible difficulty for companies to control their ideas. Another important factor had been the growing availability of private venture capital, what helped finance new companies and their efforts in commercialize ideas that were surging out of corporate research labs (CHESBROUGH, 2003). In the open innovation model, companies commercialize their own ideas as well as other companies ideas and seek to bring internal ideas to the market for development of external ways to the business (CHESBROUGH, 2003), as Figure 2 illustrates.

It may be noted in Figure 2 that research projects are no longer restricted to the boundaries of the company, including many of them being sourced from external agents. In this model, the interaction with these agents is a constant. A large number of studies (CHRISTENSEN; OLESEN; KJAER, 2005; DOGSON; GANN; SALTER, 2006; GASSMANN, 2006; VANHAVERBEKE, 2006) are adopting this term to describe the phenomena where these companies depend on external sources of innovation and demonstrate the importance of investigating how companies can implement open innovation, accentuating the importance of having "apropriate conditions" (in terms of the company strategy, capabilities of relationships nets, organizational factors, management tools, etc) to implement an open approach successfully.

Lazzarotti and Manzini (2009) identify two variables that represent the degree of openness of the process of innovation and product development in a company: the number and type of partners with whom the company collaborates and the number and type of phases of the innovation process that the company opens to external collaborations. Figure 3 illustrates these authors' reasoning.

According to Lazzarotti and Manzini (2009), the closed innovative model corresponds to the companies that access external sources of knowledge only for a specific phase of the innovation funnel. The specialized collaborators model corresponds to companies that are qualified to work with different types of partners but focus their collaboration on

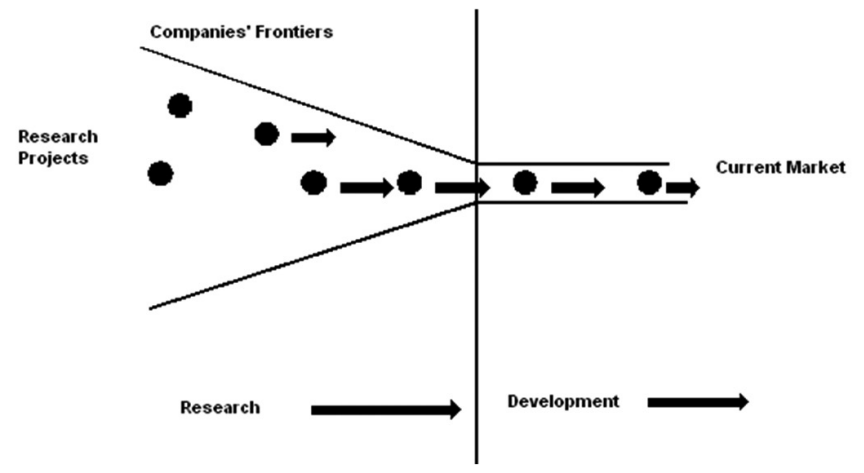

Figure 1. The Closed Innovation Model (source: CHESBROUGH, 2003).

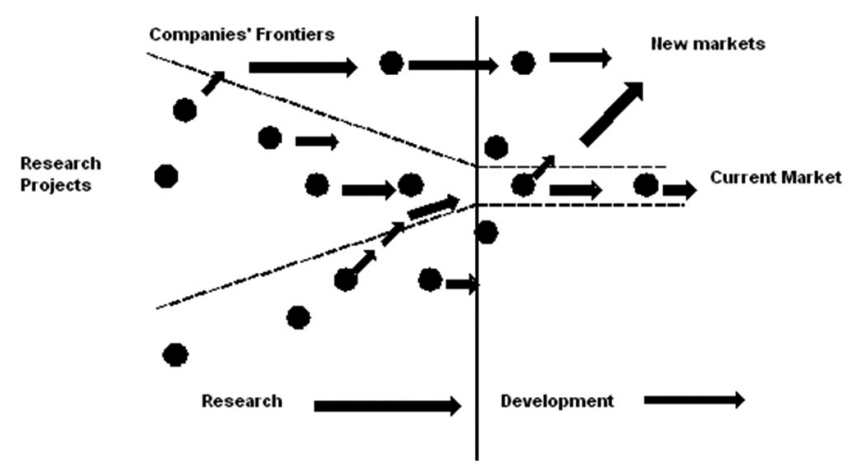

Figure 2. Open Innovation Model (source: CHESBROUGH, 2003). 
a single point of the innovation funnel - more frequently at the end. But the integrated collaborators model corresponds to companies that open their entire innovation process but contributions are only of a few partners and, finally, the open innovation model corresponds to companies that actually are able to manage a wide range of technological relationships and involve a wide range of different partners, earlier as possible in the process.

Introduced the concept of open innovation, the next topic discusses the importance and mechanisms to engage customers in the innovation process, considering especially

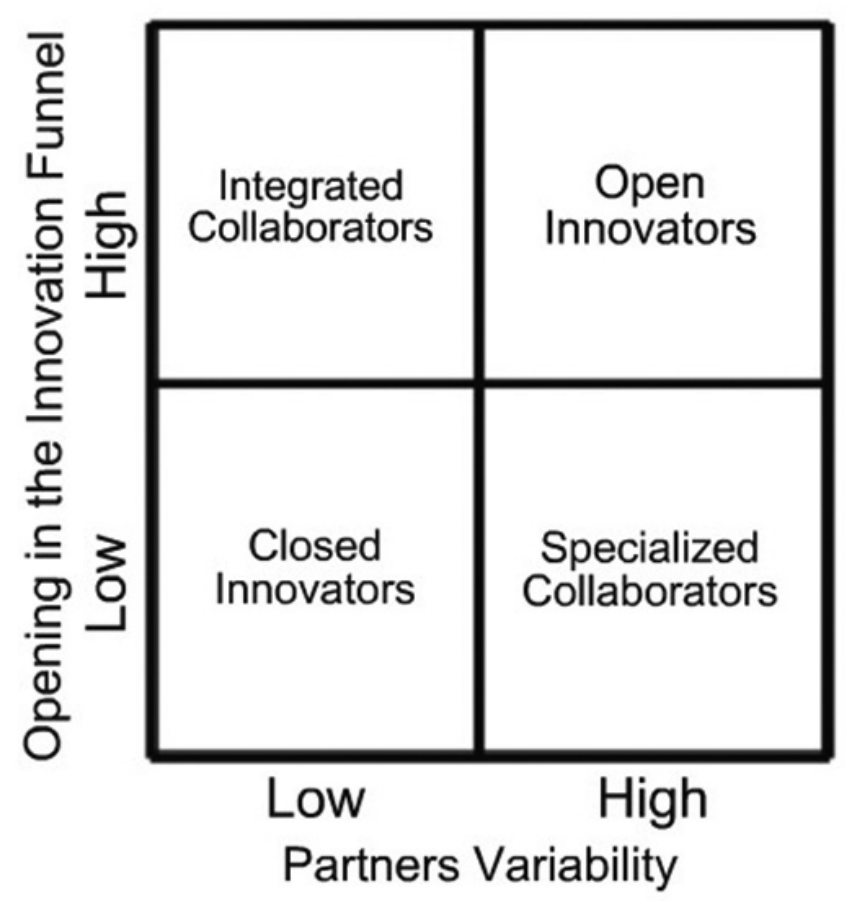

Figure 3. The four ways of opening up the innovation process (source: LAZZAROTTI; MANZINI, 2009). those involving users throughout the process of new products development.

\subsection{Involvement of users in the process of innovation and product development}

On his book "The Origins of innovation", von Hippel (1988) describes the importance of interaction with customers to develop new products. Users who participate in the innovation process can develop what they want, and interact with the company to act as its agents. In this context, von Hippel (1986) defines a special category of users called lead users who differ from ordinary users in two aspects: seeking needs months or years before the mass of consumers and are motivated and engaged in the effort to innovation.

Customers can not only be involved in discuss and generating ideas for new products, but also in co-creation with companies in final testing products and providing end-user support. As Nambisan (2002) describes, there is a variety of roles that customers can act in the products innovation and value creation. Table 1 describes these roles.

The innovations development by users, promoted by information and communication technologies, results in the existence of several types of relationships between companies and customers, in which these have different roles in the innovation process. According to Piller and Ihl (2009), three ways of costumers' participation in new products development can help to understand the different roles that lead customers to collaborate with companies, they are:

- Mode 1: Design for costumers - the products are made according to consumer preferences. The company uses information acquired by various means, such as sales feedback and groups that research consumer needs;

- Mode 2: Design with costumers - in addition to the acquired information in mode 1 , they seek solutions

Table 1. Customers' role in the New Products Development (source: NAMBISAN, 2002).

\begin{tabular}{|l|l|l|}
\hline \multicolumn{1}{|c|}{ Customer's role } & \multicolumn{1}{|c|}{ NPD Phase } & \multicolumn{1}{c|}{ Activities } \\
\hline Customer as a resource & Ideation & $\begin{array}{l}\text { - Customers' appropriation as innovation source } \\
\text { - Selection of innovative customers } \\
\text { - Necessity of several incentives to the customers } \\
\text { - Infrastructure to capture the customers' knowledge } \\
\text { - Differentiated roles of existent and potential customers. }\end{array}$ \\
\hline Customer as a co-creator & Design and Development & $\begin{array}{l}\text { - Development in a wide range of design and development tasks } \\
\text { - Context nature of new development process: industrial/consumption products. } \\
\text { - Adjustment with internal teams of NPD process. } \\
\text { - Uncertainties Management of the projects. } \\
\text { - Reinforcement of the customers' knowledge in products/technologies. }\end{array}$ \\
\hline Customer as an user & $\begin{array}{l}\text { - Scheduled Activities. } \\
\text { - Assure the customers' diversities. } \\
\text { - Continuous Activities. } \\
\text { Products Test }\end{array}$ &
\end{tabular}


and also show different concepts for consumers, so that they can react proposing other design solutions;

- Mode 3: Design by costumers - In this mode consumer's are involved in the design and products development. The company generally provides technologies mechanisms for interaction with the consumer.

The marketing literature also discusses the coproduction of value by involving consumers in new products development. Lusch (2007) classifies the production in three perspectives: "to market" where the involvement, interaction and preoccupation with costumers don't show relevance in new products development, "market(ing) to" in which the interaction and the involvement with costumers are not part of the strategy and are seen are resources and "market(ing) with", in which the costumer is considered a partner who interacts with the company and participates in the co-production of value. Santos and Brasil (2010), on the other way, describe three variables to be considered for consumer involvement in the development process of new products: the modes of consumer involvement, the stages of the development process and intensity of involvement.

Many companies seek costumers' knowledge to assist and support the process of innovation in product development. The new information and communication technologies have created new opportunities for integration with customers. The tools based on Web 2.0 can simplify integration with customers and absorption of knowledge at a low cost (PRANDELLI; VERONA; RACCAGNI, 2006).

Collaborative mechanisms based on the internet can be mapped for use in the new product development process in two important dimensions - the nature of customer involvement that is necessary, and the new product development (NPD) stage in which the client is involved. Figure 4 shows the variety of mechanisms based on Internet classifieds in two dimensions: front-end and back-end (SAWHNEY; VERONA; PRANDELLI, 2005).

Note in Figure 4 two main variables in the collaboration mechanisms based on Internet: first is the nature of collaboration and second, the phase of product development (front-end and back-end). According to these variables, some mechanisms and tools are more appropriate than others.

\section{Research method}

In order to capture information on the involvement of users in the innovation process and development of new products through the Web 2.0, an exploratory research was made, operationalized through a qualitative approach / case study. The exploratory nature is justified because although there are numerous publications on open innovation, there is a lack of research on this topic that consider the customer-
Applicability to Stage of New Product Development Process

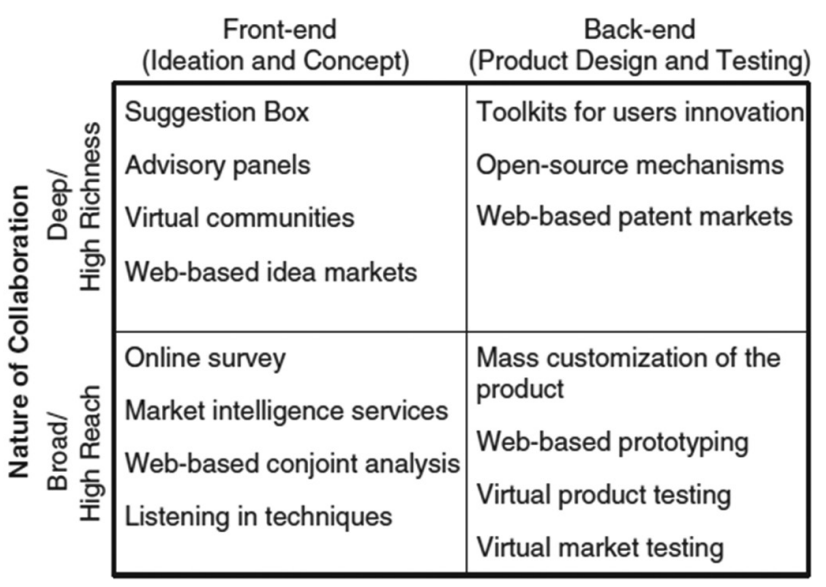

Figure 4. Collaboration mechanisms based on the Internet (SAWHNEY; VERONA; PRANDELLI, 2005).

company interaction through the internet, which occurs especially when referring to the Brazilian scenario.

A qualitative approach was used because it allows one to understand people's opinion about the studied phenomenon (Bryman, 2006), which favors even conduction of research exploratory type. Case study was used as research procedure, which according to Yin (2005) and Miguel (2007) is appropriate when seeking greater understanding of the researched facts. Moreover, according to these authors, the case study allows an intense analysis of a relatively small number of situations, and sometimes, the number of cases is reduced to one, since the emphasis is on the broad understanding of this phenomenon in such an unique and richness reality chosen for intensive research.

For data collection primary and secondary information were used. According to Yin (2005), the use of multiple sources of evidence in case studies allows the researcher to devote yourself to a wide variety of issues, such as: history, behavior and attitudes.

The unit of analysis for qualitative research / case study was operationalized by a digital media agency via web site interaction user-company in the auto project. For ethical reasons, this company will be treated in the case study by the fictitious name of Beta agency.

A script that served as the basis for an unstructured interview was structured (which was recorded to increase the reliability of the study) with the vice president of operations of this agency, after the interview data collected were transcribed. Secondary data were also collected in various sources such as books, magazines, plus access to the website about the project that allows interaction (usercompany) as web platform. 


\section{Results and case study analyses}

\subsection{Case description}

The involvement of users in the innovation process and of new products development through Web 2.0 began in 2006, when the auto company completed 30 years in Brazil. The auto company chose to celebrate the presence in the country inviting people to think about the future, with the campaign "30 years, inviting you to think about the future" which had as its protagonists children and youth. On the internet, people were able to participate in an interactive experience in an exercise that pointed what internet users from different regions, ages and social classes expect in the next 30 years. On a website, thousands of Brazilians left their impressions of the future (video, audio and text) and also discussed the world in which we live.

Still in 2006, auto company introduced its first 100\% Brazilian creation on the 24th International Motor Show, the Concept Car I, a coupe-inspired Adventure developed by the Style Centre in Brazil. Since then, studies have continued, but with a different focus: to create a vehicle on the Enviroment \& Fun concept, in other words, an environmentally friendly car that delivers driving pleasure. The result of this effort was the Concept Car II, the concept car presented at the International Motor Show in 2008. Created in auto company Development Center, a research laboratory that search new technologies, which is the starting point for the adoption of new mobility solutions with alternative materials, reusable and non-polluting.

After the FCC I and II projects, auto company also sought to work with the ideas of their customers in the design of the project. The auto company invited people to participate in the idealization and prototyping creation of FCC III, the third Concept Car to be created in Brazil Style Centre and which was presented at the Motor Show in October 2010, in São Paulo.

In Beta Agency appraisal, automakers have always been very closed to direct interaction with customers and the project generated an experience of user involvement that was essential to the success of the project. Auto company was already detecting the involvement of users through the Internet and some new trials of consumer involvement, when auto company launched the a new car in 2006, which was also used blogs, to communicate the product arrival and even the launch of the product.

For that the whole process of the auto company was possible, the automaker created a framework for development of the project and initially developed a key question that would motivate and define what would be the input for the construction of the car. To this end, a workshop was held with representatives from all functional areas of auto company, including the participation of the President of auto company in Brazil. After a day of work, new areas were created in framework development so that project phases walked along with the stages of development of the prototype.

Beta Agency was responsible for developing the collaborative platform via the internet, and also for the operational management and all digital communications strategy. The collaboration was open to consumers, opinion maker, experts, academics, so contributions of all kinds emerge, technical or not. It fell to the auto company, not the agency Beta, to organize a recovery and solution for every topic proposed by the Internet.

The project was the first car made that are under Creative Commons licenses that allow standardize the creation and distribution of content free, which converges with open innovation practices, and unlike the Copyright they facilitate the sharing of content among users. The project used these licenses to add and disseminate the ideas submitted by consumers to the site and through them, along with teams of engineering and style, a concept car was produced, the first car in the world created by and for users. The company believes that knowledge generated in this project should be unrestricted and may be used by single users or engineers and other automakers.

\subsection{Case analyses}

The analysis of this case study along with the concepts of the previous literature review resulted in an analysis of the different modes of user engagement through Web 2.0 tools in the innovation and development of new products.

According to the role of customers in new product development, proposed by Nambisan (2002), identified in the design of the project that internet users have been active as a resource in the generation and selection of ideas and also as co-creators in design and development of new concept car the automaker, including interacting with the development team automaker, through Web 2.0 tools available on the project website: forums, polls, polls, videos.

Three types of user involvement through the tools of Web 2.0 are different, as proposed by Piller and Ihl (2009): Mode 1) Design for users; Mode 2) Design with users and Mode 3) Design by users. The project fits into engagement mode 2 , because the company can acquire information and ideas of users and also show different solutions and concepts for consumers, who could then interact proposing other solutions to the automaker.

The degree of user participation in the development process of the new product was quite high and occurred through the collaboration tools available via internet. Users also had a high degree of liberty to suggest ideas or even to return to express their opinions. As proposed by Lazzarotti and Manzini (2009), besides the number and type of partners with whom the company collaborates, another important 
variable is the number and type of phases of the innovation process that the company opens to external collaboration, and in this case, the automaker took care to engage users at all stages of development of the car, providing the necessary monitoring through videos that were posted on the site. The project fits into the open innovation model.

Web 2.0 tools, as proposed by Sawhney, Verona and Prandelli (2005), available on the project were essential to the mass involvement of users in the various phases of the car construction, especially in the phases of front-end which were collected ideas and concepts for the creation of prototypes later presented to Internet users by the automaker. Other tools like forums, polls, voting, videos and own site environment that was created as a social network where Internet users can create a profile and collaborate with other users, either commenting their ideas or even voting on the best suggestions made the project be collaborative and participatory. Another important factor was the constant activations made by the company through the website or social networking sites like Twitter and Facebook, in order to engage and stimulate users participation.

\section{Final considerations}

Organizations are seeking for external sources of knowledge to use in their various organizational processes, including the process of innovation. In this context, products and services users stand out as a key player in the innovation process and so that such involvement may be done on a large scale and without boundaries, technologies and Web 2.0 tools are essential.

The project is an unprecedented case study and pioneer in automotive industry and demonstrated the involvement of users in various stages of the innovation process, such as the generation and selection of ideas, analysis and prototype evaluation. All this involvement was possible due to the website developed for the project that, used several technologies and Web 2.0 tools like forums, polls, voting and videos.

It can be noticed that the modes of user engagement through Web 2.0 require more and more virtual resources as it moves to mode 3 Piller and Ihl (2009). Another relevant issue is the way in which users are involved and maintained in the project. One should study how to keep participants motivated, and at the same time as ideas are proposed, how to select them without being dispensed potentially radical ones.

The organizations involved in the project had to be structured in order to be able to interact with internet users in various stages of development of the car, according to the internal development process of the automaker. The innovation process of the company must also be mature enough to be able to implement the new paradigm of open innovation, in which skills and knowledge are integrated to the current. A participatory organizational environment and a culture focused on process of innovation and use of new technologies also contributed in structuring companies for this innovative project.

This current exploratory study used a case selected seeking initial understandings about the involvement of users in the product development process through the web. It is expected that this study will stimulate further research on this subject and can be added to the theoretical body of open innovation. In addition, there is expectation that the results presented here assist managers interested in improving their product development practices through interaction with consumers.

\section{References}

BRYMAN, A. Integrating quantitative and qualitative research: how is it done? Qualitative Research, v. 6, n. 1, p. 97-113, 2006. http://dx.doi.org/10.1177/1468794106058877

CHESBROUGH, H. W. The era of open innovation. MIT Sloan Management Review, v. 44, n. 3, p. 35-41, 2003.

CHRISTENSEN, C. M. The Innovators Dilemma: When New Technologies Cause Great Firms to Fail. Cambridge: Harvard Business School Press, 1997.

CHRISTENSEN, J. F.; OLESEN, M. H.; KJAER, J. S. The industrial dynamics of Open Innovation - Evidence from the transformation of consumer electronics. Research Policy, v. 34, n. 10, p. 1533-1549, 2005. http://dx.doi. org/10.1016/j.respol.2005.07.002

DAHAN, E.; HAUSER, J. R. The Virtual Customer. The Journal of Product Innovation Management, v. 19, n. 5, p. 332-353, 2002. http://dx.doi.org/10.1016/S07376782(02)00151-0

DOGSON, M.; GANN, D.; SALTER, A. The role of technology in the shift towards open innovation: The case of Procter \& Gamble. R\&D Management, v. 36, n. 3, p. 333-346, 2006. http://dx.doi.org/10.1111/j.1467-9310.2006.00429.x

DRUCKER, P. The coming of the new organization. Harvard Business Review, v. 66, n. 1, p. 45-53, 1988.

GASSMANN, O. Opening up the innovation process: Towards an agenda. R\&D Management, v. 36, n. 3, p. 223-228, 2006. http://dx.doi.org/10.1111/j.1467-9310.2006.00437.x

LAZZAROTTI, V.; MANZINI, R. Different modes of open innovation: a theoretical framework and an empirical study. International Journal of Innovation Management, v. 13, n. 4, p. 615-636, 2009. http://dx.doi.org/10.1142/ S1363919609002443

LETTL, C.; HERSTATT, C.; GEMUENDEN, H. G. Learning from users for radical innovation. International Journal Technology Management, v. 33, n. 1, 2006. http://dx.doi. org/10.1504/IJTM.2006.008190 
LUSCH, R. F. Marketing's envolving identify: defining our future. American Marketing Association, v. 26, n. 2, p. 25-45, 2007.

MATTOS, C. A.; LAURINDO, F. J. B. The role of the web in improving customer input to the service/product development process: Brazilian cases. Product: Management \& Development, v. 6, n. 1, 2008.

MIGUEL, P. A. C. Estudo de caso na Engenharia de produção: estruturação e recomendações para sua condução. Revista Produção, v. 17, n. 1, p. 216-229, 2007. http://dx.doi. org/10.1590/S0103-65132007000100015

NAMBISAN, S. Designing virtual customer environments for new product development. Academy of Management Review, v. 27, n. 3, p. 392-413, 2002.

PILLER, F. T.; IHL, C. Open innovation with customers. Technology and innovation management group. RWTH Aachen University, 2009.

PRANDELLI, E.; VERONA, G.; RACCAGNI, D. Diffusion of Web-Based Product Innovation. California Management Review, v. 48, n. 4, p. 109-135, 2006. http://dx.doi. org/10.2307/41166363

RYZHKOVA, N. The contribution of the user innovation methods to open innovation. School of Management, Blekinge Institute of Technology, 2009.

SANTOS, C. R.; BRASIL, V. S. Envolvimento do consumidor em processos de desenvolvimento de produtos: um estudo qualitativo junto a empresas de bens de consumo. Revista de Administração de Empresas, v. 50, n. 3, p. 300-311, 2010. http://dx.doi.org/10.1590/S0034-75902010000300006
SAWHNEY, M.; VERONA, G.; PRANDELLI, E. Collaborating to create: the internet as a plataform for customer engagement in product innovation. Journal of Interactive Marketing, v. 19, n. 4, p. 4-17, 2005. http://dx.doi.org/10.1002/dir.20046

VANHAVERBEKE, W. The interorganisational context of Open Innovation. In: CHESBROUGH, H.; VANHAVERBEKE, W.; WEST, J. (Eds.). Open Innovation: Researching a New Paradigm. Oxford: Oxford University Press, 2006. PMid:16965331.

VRANDE, V. V. et al. Open innovation in SMEs: trends, motives and management challenges. Technovation, v. 29, n. 6-7, p. 423-437, 2009. http://dx.doi.org/10.1016/j. technovation.2008.10.001

VON HIPPEL, E. Lead ysers: A source of novel products concepts. Management Science, v. 32, n. 7, p. 791-805, 1986. http://dx.doi.org/10.1287/mnsc.32.7.791

VON HIPPEL, E. The Sources of Innovation. New York: Oxford University Press, 1988.

WENTZ, L. At fiat in Brazil, vehicle design is no longer by Fiat: Automaker is Relying on Consumers and Social Media for a 2010 Concept Car. 2010. Disponível em: < http:// adage.com/results?endeca $=1 \&$ return=endeca\&search offset $=0 \&$ search_order_by $=$ score $\& x=0 \& y=0 \&$ search_ph rase $=\mathrm{At}+\mathrm{Fiat}+\mathrm{in}+\mathrm{Brazil} \% 2 \mathrm{C}+$ Vehicle + Design $+\mathrm{Is}+\mathrm{No}+\mathrm{L}$ onger+By+Fiat $>$. Acesso em: out. 2010.

YIN, R. K. Estudo de caso: planejamentos e métodos. 3. ed. Porto Alegre: Bookman, 2005. 